GEOGRAFICKÝ ČASOPIS / GEOGRAPHICAL JOURNAL 72 (2020) 4, 351-370

DOI: https://doi.org/10.31577/geogrcas.2020.72.4.18

\title{
SPRÁVA POVODŇOVÉHO RIZIKA NA SLOVENSKU: DOČKÁME SA ZMIEN?
}

\author{
L'ubomír Solín* \\ * Geografický ústav SAV, Štefánikova 49, 81473 Bratislava, Slovensko, geogsol@savba.sk
}

\begin{abstract}
Flood risk governance in Slovakia: will we get change?
The aim of the paper is to apply the analytical framework of the EU-FP7 STARFLOOD project to analyse flood risk governance in Slovakia and to answer the question whether the change of the social and political system in Slovakia in 1989 as well as the ongoing climate change and the change of the flood risk paradigm has somehow been reflected in the governance flood risk. Despite many impulses for change, the analysis has shown that centralized flood risk governance by the state persists and the strategy of flood protection through technical flood infrastructure dominates in Slovakia. However it is argued that, this type of flood risk governance is unsustainable in the long term and some decentralization and diversification of flood risk governance is required to increase the societal resilience to flood risk and adapt to climate change.
\end{abstract}

Key words: flood risk governance, policy arrangement approach, flood defence, diversity, decentralization, Slovakia

\section{ÚVOD}

Analýza historického vývoja prístupu l’udskej spoločnosti k riešeniu problematiky povodní poukazuje na neustály „boj“ človeka s povodňami, ktorý sa človek snaží „vyhrat"“ budovaním rôznych hrádzí a vodných nádrží slúžiacich na ochranu pred zaplavením (Plate 2002). Nárast negatívnych povodňových dôsledkov, ktorý je spôsobený zvýšenou frekvenciou výskytu povodní, ako aj ich extrémnost'ou v dôsledku meniacej sa klímy však vyvoláva určité pochybnosti a obavy, či stále dominujúci technický koncept ochrany pred povodňami bude schopný zvládnut' narastajúce povodňové ohrozenie a jeho dôsledky (Di Baldassarre et al. 2018). Otázniky nad efektívnost'ou riešenia problematiky povodní výlučne technickou protipovodňovou infraštruktúrou sa však objavovali už skôr. Dôležitým impulzom na riešenie problematiky povodní bola zmena paradigmy povodňového rizika $\mathrm{v} 70$. rokoch 20 . storočia (Plate 2002, Wisner et al. 2004, Johnson et al. 2005 a Werrity 2006). V jej pozadí je idea, že pri hodnotení prírodných katastrof musí byt' rovnaká pozornost', aká sa venuje hodnoteniu samotného prírodného javu, venovaná aj hodnoteniu zranitel'nosti spoločnosti (Wisner et al. 2004). Taktiež meniaci sa hodnotový systém spoločnosti a považovanie zachovania udržatel'ného environmentálneho systému za všeobecne prospešnú hodnotu sa v 90. rokoch 20. storočia (Plate 2002) prejavil tlakom na aplikáciu „zelených riešení“ pri znižovaní povodňového ohrozenia (Morris et al. 2016). Vhodným príkladom, na ktorom sa dá ilustrovat' vplyv uvedených impulzov na zmeny $\mathrm{v}$ riešení problematiky povodní, je vývoj povodňového manažmentu v povojnovom období v Anglicku a Walese (tab. 1).

Napomôct' prechodu od ochrany pred povodňami $\mathrm{k}$ integrovanému manažmentu povodňového rizika sa snaží aj legislatíva EÚ (Smernica EÚ 2007). Tento proces však nie je jednoduchý. Spravidla je spojený so zmenou riadenia a organizácie manažmentu povodňového rizika. Viaceré štúdie, napr. Klijn et al. (2008), Bubeck et 
al. (2017) alebo štúdie v rámci projektu EU-FP7 STAR-FLOOD (Mees et al. 2016 a 2018, Wiering et al. 2017, Fournier et al. 2018, Kaufmann 2018, Lifferink et al. 2018 a Matczak et al. 2018), poukazujú na určité diferencie medzi krajinami z hl'adiska správy povodňového rizika. Napríklad v krajinách ako Holandsko a Pol'sko je správa povodňového rizika centralizovane riadená štátom a $\mathrm{V}$ manažmente povodňového rizika dominuje ochrana pred povodňami technickou infraštruktúrou. V prípade Holandska nadobúda až črty národnej kultúry a nevyhnutnost' ochrany pred povodňami výstavbou technických zariadení je ukotvená dokonca aj v ústave. Naproti tomu výraznú decentralizovanú správu povodňového rizika spolu s uplatňovaním diverzifikovaných stratégií manažmentu povodňového rizika pozorujeme v Anglicku. Snahu o diverzifikovaný manažment povodňového rizika vidiet' aj Belgicku a Nemecku. Správa povodňového rizika v týchto štátoch odráža ich federatívne usporiadanie a je pod kontrolou regiónov, resp. spolkových republík. V akomsi prechodnom období sa nachádza Francúzsko. Napriek decentralizovanej verejnej správe je správa povodňového rizika stále výrazne centralizovaná a riadená štátom.

Tab. 1. Vývoj protipovodňovej ochrany v Anglicku a Walese v povojnovom období (Johnson et al. 2005)

\begin{tabular}{|c|c|c|c|}
\hline \multirow{2}{*}{$\begin{array}{c}\text { Všeobecné } \\
\text { prvky } \\
\text { protipovodňovej } \\
\text { stratégie }\end{array}$} & \multicolumn{3}{|c|}{ Stratégie } \\
\hline & $\begin{array}{l}\text { Odvodňovanie } \\
\text { pol'nohospodárskych pozem- } \\
\text { kov (do } 70 \text {. rokov } 20 \text {. stor.) }\end{array}$ & $\begin{array}{l}\text { Ochrana pred povodňami } \\
\text { (80. a 90. roky 20. stor.) }\end{array}$ & $\begin{array}{l}\text { Manažment povodňového } \\
\text { rizika (od roku 2000) }\end{array}$ \\
\hline $\begin{array}{l}\text { Postavenie } \\
\text { človeka }\end{array}$ & $\begin{array}{l}\text { Človek má dominantné } \\
\text { postavenie nad prírodou. } \\
\text { Príroda je tu pre využitie } \\
\text { človekom }\end{array}$ & $\begin{array}{l}\text { Človek má dominantné } \\
\text { postavenie nad prírodou } \\
\text { (moc a právo je použité } \\
\text { na jej využivanie) }\end{array}$ & $\begin{array}{l}\text { Človek je súčast'ou } \\
\text { prírody, nie je nad ňou } \\
\text { nadradený }\end{array}$ \\
\hline $\begin{array}{l}\text { Prioritné } \\
\text { hodnoty }\end{array}$ & $\begin{array}{l}\text { Priorita je kladená na } \\
\text { pol'nohospodársku } \\
\text { produkciu a potravinovú } \\
\text { bezpečnost' v rámci } \\
\text { národného ekonomického } \\
\text { kontextu }\end{array}$ & $\begin{array}{l}\text { Priorita je kladená na ekono- } \\
\text { mický rast, národnú } \\
\text { bezpečnost' a zachovanie } \\
\text { blahobytu }\end{array}$ & $\begin{array}{l}\text { Ekologické } \\
\text { a environmentálne } \\
\text { hodnoty by mali byt' posu- } \\
\text { dzované v parite } \\
\text { s ekonomickým rastom, } \\
\text { národnou bezpečnost'ou } \\
\text { a zachovaním blahobytu }\end{array}$ \\
\hline Ciel' stratégie & $\begin{array}{l}\text { Zlepšit' a chránit' } \\
\text { pol'nohospodársku pôdu } \\
\text { pred povodňami }\end{array}$ & $\begin{array}{l}\text { Ochrana l'udí a majetku } \\
\text { pred povodňami }\end{array}$ & $\begin{array}{l}\text { Manažovat' povodňové } \\
\text { riziko spravodlivo v zhode } \\
\text { s princípmi trvalo } \\
\text { udržatel'ného } \\
\text { ekologického rozvoja }\end{array}$ \\
\hline $\begin{array}{l}\text { Postupy } \\
\text { stratégie }\end{array}$ & $\begin{array}{l}\text { Investície do odvodňovania } \\
\text { a protipovodňovej ochrany } \\
\text { vidieckej krajiny }\end{array}$ & $\begin{array}{l}\text { Investovanie do protipovod- } \\
\text { ňovej ochrany miest } \\
\text { uplatňujúc pritom kritériá } \\
\text { národnej dôležitosti } \\
\text { a finančnej efektívnosti }\end{array}$ & $\begin{array}{l}\text { Zameranie na rozhodnutia, } \\
\text { ktoré zabezpečujú sociálne } \\
\text { a ekonomické potreby } \\
\text { a zároveň udržujú kvalitu } \\
\text { ekosystému }\end{array}$ \\
\hline
\end{tabular}

Slovensko je krajina, v ktorej sa za posledných 30 rokov udiali viaceré významné spoločenské zmeny. V roku 1989 sa zmenil spoločenský a politický systém. Totalitný systém bol zrušený a spravovanie spoločnosti sa začalo uskutočňovat' na báze demokratických princípov. Realizovala sa výrazná reorganizácia štátnej správy a vytvorili sa samosprávne orgány na regionálnej a miestnej úrovni. V roku 2004 sa Slovensko stalo členom EU a do svojho legislatívneho systému začalo implementovat' smernice a nariadenia Európskeho parlamentu a Rady. Slovensko sa stalo otvorenou spoločnost'ou, v ktorej významný vplyv vo verejnom sektore začali 
mat' mimovládne organizácie. V tomto kontexte je preto namieste otázka, či uvedené spoločenské a legislatívne zmeny, snaha o zachovanie udržatel'ného environmentálneho systému, zmena paradigmy povodňového rizika, ako aj vyrovnanie sa s negatívnymi dôsledkami prebiehajúcej klimatickej zmeny sa nejako prejavili v správe povodňového rizika $\mathrm{z}$ hl'adiska jeho organizácie, riadenia i vecnej náplne, t. j. uplatňovaných stratégií a opatrení. Dat' odpoved' na túto otázku je ciel'om nášho príspevku.

\section{TEORETICKÝ RÁMEC HODNOTENIA DYNAMIKY SPRÁVY POVODŇOVÉHO RIZIKA}

Hodnotenie dynamiky správy povodňového rizika v SR sa uskutočňuje na základe analytického rámca, ktorý bol použitý pri analýze dynamiky správy povodňového rizika $v$ rámci projektu STAR-FLOOD (www.starflood.eu). Hodnotiaci rámec považuje správu povodňového rizika za verejnú službu, ktorá je charakterizovaná štyrmi dimenziami: 1) aktéri a koalície aktérov, 2) moc a zdroje, 3) pravidlá fungovania a 4) verejná diskusia (Heger et al. 2016). Ak nie je zmena v žiadnej dimenzii, je organizácia a riadenie povodňového rizika považované za stabilné. Pri zmene v jednej alebo dvoch dimenziách sa dynamika organizácie a riadenie povodňového rizika považuje za mierne zmenenú a ak sú zmeny vo všetkých dimenziách, dochádza k výraznej zmene správy povodňového rizika. Proces zmeny býva zriedkavo radikálny a spravidla má charakter postupnej transformácie, ktorá môže nadobúdat' niektorú $\mathrm{z}$ foriem uvedených $\mathrm{v}$ tab. 2.

Tab. 2. Spôsoby transformácie organizačnej štruktúry (Streeck a Thelen 2005)

\begin{tabular}{ccc}
\hline Spôsob transformácie & Definícia & Mechanizmus \\
\hline Vytesnenie (odstránenie) & $\begin{array}{c}\text { Postupný nárast významu podriadených } \\
\text { zložiek vzhladom na dominantné inštitúcie }\end{array}$ & Nahradenie \\
\hline Vrstvenie & $\begin{array}{c}\text { Pripojenie nových prvkov k existujúcim } \\
\text { inštitúciám a postupná zmena ich statusu } \\
\text { a štruktúry }\end{array}$ & Relatívny rast \\
\hline Posun & $\begin{array}{c}\text { Zanedbanie inštitucionálnej údržby napriek } \\
\text { externej zmene, ktorá má za následok } \\
\text { zosunutie inštitucionálnej praxe na dno }\end{array}$ & Zámerné zanedbanie \\
\hline Prestavba & $\begin{array}{c}\text { Prestavba starých inštitúcí́ pre nové ciele, } \\
\text { nové ciele sú pripojené k starým } \\
\text { štruktúram }\end{array}$ & Presmerovanie a reinterpretácia \\
\hline Únava & Postupný rozklad inštitúcií v priebehu času & Vyčerpanie
\end{tabular}

Vysvetlenie príčin stability a zmeny správy povodňového rizika sa opiera o teoretický rámec, ktorý rozpracovali Wiering et al. (2018). Tento rámec vychádza z definovania „síl stability“ a „síl zmeny“, ktoré sú analyzované vo vzt’ahu k štyrom základným dimenziám verejnej správy (tab. 3). Sily stability sa prejavujú zachovaním existujúceho stavu. Kl'účovým aspektom síl stability je teória „,cesty zotrvačnosti“, podl'a ktorej kroky predchádzajúceho smerovania ovplyvňujú budúce smerovanie (Pierson 2000). Wiering et al. (2018) zdôrazňujú, že teória zotrvačnosti okrem svojej historizujúcej črty objasňujúcej stabilný vývoj je nápomocná aj pri jeho objasňovaní $\mathrm{z}$ dôvodu presvedčenia, že existujúce cesty je $\mathrm{z}$ rôznych dôvodov vel'mi t'ažké opustit' či zmenit'. Neochota niečo zmenit' môže pramenit' aj z pochopenia stabilizujúcich alebo reprodukčných mechanizmov. 
Stabilizujúce mechanizmy: 1) fixné náklady, 2) efekty vzdelávania, 3) efekty koordinácie a 4) adaptačné očakávania, ktoré Arthur (1988) a North (1990) identifikovali v oblasti trhovej ekonomiky, špecifikovali Wiering et al. (2018) na povodňové riziko (tab.3).

Tab. 3. Sily stability a zmeny spojené s dimenziami verejnej správy (Wiering et al. 2018)

\begin{tabular}{|c|c|c|}
\hline Sily stability & Dimenzie verejnej správy & Sily zmeny \\
\hline $\begin{array}{l}\text { - Koordinačné efekty: Spravovanie rizika } \\
\text { špecifickými sektormi s akceptovanou } \\
\text { zodpovednostou }\end{array}$ & Aktéri a koalície & $\begin{array}{l}\text { - Aktivisti dávajúci do pozornosti } \\
\text { nedostatočné riadenie } \\
\text { - Silný tlak špecifických záujmov }\end{array}$ \\
\hline $\begin{array}{l}\text { - Fixné náklady a zvyšovanie návratnosti } \\
\text { prostredníctvom vel'kých investícií } \\
\text { do protipovodňovej infraštruktúry } \\
\text { (,potopené náklady“) } \\
\text { - Vzdelávacie efekty: vývoj silnej základne } \\
\text { poznatkov a vzdelanej spoločnosti }\end{array}$ & Moc a zdroje & $\begin{array}{l}\text { - Pochybnosti o zvyšovaní } \\
\text { nákladov na protipovodňovú } \\
\text { infraštruktúru alebo náhly } \\
\text { výpadok zdrojov otvárajúci } \\
\text { priestor pre alternatívne možnosti } \\
\text { - Nové expertízy (poznatky) }\end{array}$ \\
\hline $\begin{array}{l}\text { - Legislatíva má silný stabilizačný efekt } \\
\text { pri formalizácii pravidiel a procedúr } \\
\text { verejnej správy }\end{array}$ & Pravidlá fungovania & $\begin{array}{l}\text { - Znižovanie legitímnosti } \\
\text { existujúcich pravidiel } \\
\text { - Nové pravidlá (napr. smernice EÚ) }\end{array}$ \\
\hline $\begin{array}{l}\text { - Silné historické naratívy } \\
\text { Adaptačné očakávania: vysoká miera } \\
\text { dôvery verejnosti v existujúce inštitúcie } \\
\text { a ich efektívnost' }\end{array}$ & Verejná diskusia & $\begin{array}{l}\text { - Znižovanie dôvery v existujúce } \\
\text { inštitúcie a presvedčenia o ich } \\
\text { efektívnosti } \\
\text { - Nové myšlienky, nová definícia } \\
\text { problémov verejných politík } \\
\text { vedúca k protichodným } \\
\text { naratívom }\end{array}$ \\
\hline
\end{tabular}

V súvislosti so silami zmeny poukazujú Wiering et al. (2018) na tri významné analytické rámce konceptualizujúce politiku zmeny: rámec viacnásobných línií, rámec podporovaný koalíciou aktérov, rámec odbornej diskusie. Významným faktorom zmeny sú aj katastrofické udalosti, ktoré otvárajú „okno príležitosti““.

Rámec viacnásobných línií (Multiple Streams Framework - MSF) zahrnuje tri základné línie. Prvú líniu tvoria klúčové informácie o probléme, politickej garnitúre a o riešení problému. Druhou líniou je okno príležitostí a tretiu líniu vytvárajú osobnosti verejného života. MSF predpokladá, že vzájomná väzba medzi problémom, politikmi a riešením nie vždy funguje. Alternatívne riešenia problému majú šancu dostat' sa do pozornosti verejnosti predovšetkým v čase výskytu extrémnych hydrologických javov (okno príležitostí). A je na osobnostiach verejného života (environmentálnych aktivistoch), aby pre nové riešenia problému získali politickú podporu. Ak to dosiahnu, tak jednotlivé línie (problém - politici - riešenie) budú vzájomne prepojené a môže dôjst' $\mathrm{k}$ zmene.

Rámec podporovaný koalíciou aktérov vychádza z predpokladu, že každý subsystém politiky verejnej správy je podporovaný aktérmi s podobným názormi a myšlienkami, ktorí sút'ažia s inými skupinami aktérov, ktorých názory a myšlienky sú iné. Aktéri koalície zdielajú medzi sebou určité hodnotové presvedčenie, ako aj presvedčenie o vážnosti problému, ktoré len vel'mi t’ažko menia. Na druhej strane sú však myšlienky a témy, o ktorých sú koalície aktérov ochotné medzi sebou diskutovat' a robit' vzájomné ústupky. $\mathrm{K}$ zmene organizácie a riadenia povodňového 
rizika spravidla dochádza pod tlakom vel'mi závažných externých faktorov (napr. prírodné katastrofy alebo iné šokujúce javy), ktoré dokážu zmenit' hodnotové presvedčenie, ako aj presvedčenie o vážnosti problému.

V prípade rámca verejnej diskusie je nevyhnutné v odbornej diskusii presvedčit' iných aktérov, aby podporili vaše myšlienky, argumentáciu a nový koncept riešenia problému. Čím je diskusný rámec otvorenejší, zahrnujúci pomerne široké spektrum myšlienok, tým väčšia je šanca pripojenia ostatných aktérov. Aby však nastala zmena, tak je potrebné okrem zjednotenia aktérov dosiahnut' mobilizáciu smerujúcu k zmene aj v ostatných dimenziách riadenia verejnej správy.

Analýza dynamiky správy povodňového rizika v SR na základe dimenzií verejnej správy a pôsobenia síl stability a zmeny sa opiera o poznanie vývoja vodného hospodárstva a legislatívneho rámca ochrany pred povodňami v SR. Stručne tieto aspekty rozoberieme $\mathrm{v}$ nasledovných častiach príspevku.

\section{VÝVOJ ORGANIZÁCIE A RIADENIA VODNÉHO HOSPODÁRSTVA V SR}

Manažment povodňového rizika je jedným z aspektov vodohospodárstva. Preto vývoj organizácie a riadenia manažmentu povodňového rizika je nevyhnutné posudzovat' v kontexte chronológie vodného hospodárstva. V procese vývoja získavala postupne problematika povodní v rámci vodného hospodárstva stále väčší význam. Z pohl'adu organizácie a riadenia je vhodné rámcovat' ju štyrmi obdobiami.

\section{Obdobie do roku 1945}

Novodobé legislatívne počiatky formujúce organizáciu a riadenie vodného hospodárstva v SR siahajú do druhej polovice 19. storočia a boli dané uhorským právom. Na jeho základe sa v povodí Dunaja a Tisy začali zriad'ovat' vodné družstvá so snahou regulovat' vodný režim tokov a ochránit' tak pril'ahlé územia proti zaplaveniu, či už vodou z rieky alebo vnútornými vodami (Hanušin 1986 a Jambor 2016). Uhorská právna norma týkajúca sa vôd pre Slovensko platila aj po roku 1918 počas celého trvania prvej česko-slovenskej republiky (Vondrušková 2012). K zásadným zmenám dochádza až v 50. rokoch 20 . storočia.

\section{Obdobie rokov $1945-1965$}

V tomto období je spravovanie vodného hospodárstva riadené vládou, ústrednými orgánmi štátnej správy a výkonnými orgánmi krajských a okresných národných výborov. Vládnym nariadením (Vládne nariadenie 92 zo dňa 27. novembra 1953 Z. z.) sa zriadila Ústredná správa vodného hospodárstva ako ústredný orgán so sídlom v Prahe a Správa vodného hospodárstva na Slovensku. Následne sa zákonom o vodnom hospodárstve (Zákon č. 11/1955 Z. z.) zrušili dovtedy platné zákonné predpisy týkajúce sa hospodárenia a využívania vody, v dôsledku čoho došlo aj k zrušeniu vodných družstiev. Podl'a uvedeného zákona sa vodohospodárskymi orgánmi stali:

a) Ústredná správa vodného hospodárstva a Správa vodného hospodárstva na Slovensku,

b) výkonné orgány národných výborov.

Ústredná správa vodného hospodárstva vykonávala svoje úlohy v tom čase priamo alebo cez zriadené organizácie. Možnost' zriad’ovat' organizácie na vykonáva- 
nie úloh vodného hospodárstva mali aj výkonné orgány krajských národných výborov. Počet aj pôsobnost' organizácií vodného hospodárstva, ktoré zriad'ovali, sa však menil s administratívnym členením ČSSR. V období rokov 1949 - 1960 platilo administratívne členenie Slovenska na šest' krajov. Krajské národné výbory, ktoré stali na ich čele, zriadili na vykonávanie úloh vodného hospodárstva krajské správy vodných tokov a meliorácií a krajské správy vodovodov a kanalizácií. Uvedené administratívne členenie bolo zrušené v roku 1960. V rámci nového administratívneho členenia (Zákon č. 36/1960 Z. z.) sa na území Slovenska vytvorili tri kraje: Západoslovenský (11 okresov), Stredoslovenský (13 okresov), Východoslovenský (13 okresov). Krajské správy vodných tokov a meliorácií a krajské správy vodovodov a kanalizácií boli zrušené a ich pôsobnost' a kompetencie prešli od 1. 7 . 1960 na okresné vodohospodárske správy (OVHS), ktoré zriad'ovali okresné národné výbory (Jambor 2016). V pôsobnosti OVHS bola široká škála vodohospodárskych činností orientovaných predovšetkým na hospodárne využívanie vodných zdrojov, ich distribúciu, na ochranu a čistotu povrchových a podzemných vôd. Problematiky povodní sa týkalo len zabezpečovanie starostlivosti o všetky vodné toky, včítane tokov neupravených, a vykonávanie vodohospodárskeho dohl'adu nad nimi. Ako konštatujú Novák (2016) a Jambor (2016), na vykonávanie svojej činnosti však nemali OVHS dostatok finančných zdrojov, a preto sa prioritne venovali najmä zásobovaniu obyvatel'stva pitnou vodou. Starostlivosti o vodné toky, ako aj ochrane proti povodniam nebola venovaná dostatočná pozornost'.

\section{Obdobie rokov $1965-1989$}

Významnou skutočnost'ou, ktorá ovplyvnila organizačné usporiadanie vodného hospodárstva založeného na báze administratívnych jednotiek, bola vel'ká povodeň na Dunaji v júli v roku 1965, ktorá vznikla pretrhnutím dunajských hrádzí. Neuspokojivý stav hrádzí na ochranu pred povodňami, ako aj zanedbaná starostlivost' o vodné toky boli považované za dôležité príčiny povodne (Jambor 2016). Vláda ČSSR v snahe zlepšit' starostlivost' o vodné toky i ochranu pred povodňami prijala nariadenie, na základe ktorého vzniklo k 1. 7. 1966 Riaditel'stvo vodných tokov (RVT), ktorého podriadenými jednotkami boli správy povodí. Na Slovensku vznikli 4 správy povodí: Správa povodia Dunaja v Bratislave, Správa povodia Váhu v Piešt’anoch, Správa povodia Hrona v Banskej Bystrici, Správa povodia Bodrogu a Hornádu v Košiciach. V roku 1970 ministerstvo lesného a vodného hospodárstva pretransformovalo správy povodí RVT na štátne hospodárske organizácie. Povinnosti štátnych organizácií ako správcov vodných tokov určoval zákon o vodách (Zákon č. 138/1973 Z. z.) a podrobnejšie ich upravovala vyhláška ministerstva lesného a vodného hospodárstva (Vyhláška 1978).

Okrem štátnych hospodárskych organizácií povodí, širokú oblast' vodného hospodárstva nad'alej riadili aj nižšie orgány štátnej správy, a to miestne (mestské), okresné a krajské národné výbory. Ich pôsobnost' na úseku vodného hospodárstva upravoval zákon (Zákon č. 135/1974 Z. z.) a jeho novelizácie. Kompetencie miestnych (mestských) národných výborov sa v problematike povodní týkali len určovania zátopových území pri drobných tokoch a na dávanie súhlasu na stavby, zariadenia a činnosti v zátopových územiach. Kompetencie krajských národných výborov smerovali $\mathrm{k}$ povol'ovaniu vodohospodárskych stavieb na ochranu pred povodňami presahujúcimi územie jedného okresu a určovaniu zátopových území pri vodohospodársky významných tokoch. 


\section{Obdobie od roku 1989 po súčasnost'}

Po zmene spoločenského systému v roku 1989 boli štátne vodohospodárske organizácie pretransformované na štátne podniky, ktoré však začali mat' ekonomické problémy (Jambor 2016). Preto Ministerstvo pôdohospodárstva k 1. 7. 1997 zlúčilo štyri štátne podniky povodí do jedného podniku s názvom Slovenský vodohospodársky podnik, štátny podnik (SVP, š. p.). Pôvodné štátne podniky povodí sa stali jeho organizačnými zložkami ako odštepné závody.

$\mathrm{V}$ súvislosti $\mathrm{s}$ implementáciou rámcovej smernice EÚ o vode (Smernica EÚ 2000) sa s účinnost'ou od 1. mája 2004 vykonala organizačná zmena podniku a pôvodné odštepné závody sa zrušili. Vznikli nové odštepné závody: OZ Bratislava, OZ Piešt'any, OZ Banská Bystrica a OZ Košice. Organizačnými zložkami na vykonávanie ich činnosti sa stali správy povodí (www.svp.sk/sk/uvodna-stranka/svp/ organizacna-struktura/), ktoré sú v súlade s čiastkovými povodiami určenými v SR. Tento stav trvá až doteraz.

Dosah na riešenie problematiky povodní majú aj d’alšie tri organizácie Ministerstva životného prostredia SR (MŽP SR). Prvou je Výskumný ústav vodného hospodárstva, ktorý sa venuje aj vedeckovýskumnej činnosti v oblasti hydrotechniky, hydroenergetiky, hydrológie, riečnej morfológie a revitalizácie krajiny v povodiach. Ďalšou organizáciou je Slovenský hydrometeorologický ústav, ktorý zabezpečuje hydrologické merania na vodných tokoch, stanovuje návrhové veličiny maximálnych prietokov s vel'kou, strednou a malou pravdepodobnost'ou výskytu a vydáva povodňové výstrahy. A tret'ou organizáciou je Vodohospodárska výstavba, štátny podnik, ktorá sa zaoberá výstavbou vodných diel s hydroenergetickým využitím.

Po zmene spoločenského systému v roku 1989 dochádza prijatím zákona o obecnom zriadení (Zákon č. 369/1990 Z. z.) a zákona o samospráve (Zákon č. 302/2001 Z. z.) k decentralizácii verejnej správy na štátnu správu a samosprávu. Za samostatný samosprávny celok na miestnej úrovni je považovaná obec a na regionálnej úrovni je to vyšší územný celok (VUC) - samosprávny kraj. Zrušenie národných výborov ako výkonných orgánov štátnej správy si vyžiadalo zmenu územnej organizácie štátnej správy. Súčasná územná organizácia štátnej správy je daná zákonom (Zákon č. 180/2013 Z. z.), podl’a ktorého orgánmi miestnej štátnej správy sú okresné úrady v sídle kraja (osem úradov) a okresné úrady (72 úradov). Orgánmi ústrednej štátnej správy sú ministerstvá. V rámci okresných úradov zabezpečuje výkon štátnej správy na úseku ochrany pred povodňami odbor starostlivosti o životné prostredie. Dôležitým aspektom verejnej správy je okrem územnej organizácie delimitácia kompetencií medzi novovytvorenými orgánmi štátnej správy (okresné úrady v sídle kraje, okresné úrady) a samosprávnymi celkami na miestnej a regionálnej úrovni. $\mathrm{Na}$ obce priamo prešla pôsobnost' miestnych (mestských) národných výborov (originálne kompetencie) a čast' kompetencií z okresných a národných výborov (prenesené kompetencie).

\section{LEGISLATÍVNY RÁMEC OCHRANY PRED POVODŇAMI}

Podl’a súčasne platných zákonov (Zákon č.7/2010 Z. z. a Zákon č.71/2015 Z. z.) sú orgánmi zodpovednými za riadenie a zabezpečenie ochrany pred povodňami: MŽP SR, okresné úrady v sídle kraja a okresné úrady. Ďalej zákon uvádza, že ochranu pred povodňami riadia a zabezpečujú aj obce a vyššie územné celky (VÚC). 
MŽP SR je najvyšší štátny orgán ochrany pred povodňami a vykonávanie úloh ochrany pred povodňami zabezpečuje prostredníctvom organizácií, ktoré má vo svojej pôsobnosti. Z nich má najvýznamnejšie postavenie SVP, š. p. Základnou náplňou SVP, š. p., je zabezpečovanie činností súvisiacich so správou vodných tokov a správou povodí a zabezpečovanie činností verejnoprospešného charakteru, z ktorých ochrana pred povodňami patrí medzi najvýznamnejšie. V rámci správy vodných tokov a povodí zabezpečuje starostlivost' o vodné toky a o hmotný investičný majetok (vodné nádrže, poldre a ochranné hrádze), ktorý je na nich vybudovaný. Na základe rozhodnutia MŽP SR v pôsobnosti SVP, š. p., je aj gescia nad vypracovaním, prehodnotením a aktualizáciou úloh smernice EÚ (Smernica EÚ 2007), t. j. predbežného hodnotenia povodňového rizika, vypracovanie máp povodňového ohrozenia, máp povodňového rizika a plánov manažmentu povodňového rizika.

Vykonávat' protipovodňové opatrenia priamo na vodných tokoch, resp. realizovat' opatrenia súvisiace $s$ údržbou vodných tokov, je oprávnený len správca vodných tokov. Okrem SVP, š. p., ktorý z celkovej dížky 61147 km vodných tokov v SR spravuje 62 \% (SVP 2018), takú pôsobnost' majú aj organizácie lesného hospodárstva Ministerstva pôdohospodárstva a rozvoja vidieka SR, ktoré spolu spravujú $32 \%$ z celkovej dĺžky drobných vodných tokov. Obce sa na správe drobných vodných tokov podiel'ajú minimálne. Len $1 \%$ drobných tokov je v správe obcí.

Činnost' ostatných štátnych orgánov ochrany pred povodňami, t. j. okresných úradov v sídle kraja a okresných úradov, je orientovaná okrem riadenia a koordinácie vykonávania opatrení na ochranu pred povodňami na území kraja, resp. okresu, aj na spoluprácu s SVP, š. p., pri realizácii úloh hodnotenia a manažmentu povodňového rizika.

Pôsobnost' obcí pri preventívnej ochrane pred povodňami je vykonávaná v rámci preneseného výkonu štátnej správy. Obec podl’a § 26 Zákona č.7/2010 Z. z. riadi a zabezpečuje vykonávanie opatrení na ochranu pred povodňami v rámci katastrálneho územia, d’alej spolupracuje s SVP, š. p. na vypracovaní a aktualizáciách predbežného hodnotenia povodňového rizika, máp povodňového rizika a vyhotovení plánov manažmentu povodňového rizika. Obec sa podiel'a na príprave návrhov preventívnych opatrení v katastrálnom území, ktoré spomal'ujú odtok z povodia, zmenšujú maximálny prietok alebo chránia územie pred zaplavením, a navyše podl'a svojich možností aj participuje na ich vykonávaní. Medzi dôležité činnosti obcí patrí aj povol'ovanie stavieb a určovanie regulatív priestorového usporiadania a funkčného využívania inundačných území v územnom pláne obce. Okrem toho starosta obce vyhlasuje a odvoláva stupne povodňovej aktivity, resp. mimoriadnu situáciu, ak hrozí bezprostredné ohrozenie životov, zdravia a majetku obyvatel'ov obce, ako aj kultúrneho dedičstva $\mathrm{v}$ dôsledku povodne.

Pôsobnost' VÚC na úseku ochrany pred povodňami zahrňuje spoluprácu s SVP, š. p., s orgánmi štátnej správy a obcami na vypracovaní a aktualizáciách predbežného hodnotenia povodňového rizika a plánov manažmentu povodňového rizika v rámci územia vyššieho územného celku. A d’alej využíva výsledky hodnotenia povodňového rizika na určenie regulatív priestorového usporiadania a funkčného využívania územia v procesoch územného plánovania. 


\section{HODNOTENIE DYNAMIKY SPRÁVY POVODŇOVÉHO RIZIKA NA ZÁKLADE DIMENZIÍ VEREJNEJ SPRÁVY}

Analyzovanie prezentovaného vývoja vodného hospodárstva poskytuje nasledovné výsledky týkajúce sa dynamiky správy povodňového rizika $\mathrm{z}$ hladiska štyroch dimenzií správy verejnej služby.

\section{Dimenzia: aktéri a ich zoskupenia}

Od 50. rokov 20. storočia rozhodujúcimi aktérmi organizácie a riadenia povodňového rizika sú orgány a organizácie štátnej správy. Úloha orgánov samospráv po transformácii verejnej správy po roku 1989 je menej dôležitá. Štátna správa bola niekol'kokrát reorganizovaná, $\mathrm{v}$ dôsledku čoho sa menil charakter aktérov štátnej správy. Z hl'adiska organizácie a riadenia povodňového rizika sa javia ako významné nasledovné zmeny. Prvou je ústup od organizácie a riadenia ochrany pred povodňami na báze administratívneho členenia $\mathrm{v}$ roku 1966 a prechod $\mathrm{k}$ riadeniu na báze povodí prostredníctvom štátom riadených správ vodných tokov. Správa povodňového rizika na báze štyroch správ povodí trvala až do roku 1997, ked' došlo k ich zlúčeniu do jedného podniku s názvom Slovenský vodohospodársky podnik, š. p. Toto spojenie je druhou výraznou zmenou, ktorou sa posilnil charakter centralizovanej štátnej správy organizácie a riadenia povodňového rizika v SR. Z pohl'adu aktérov správy povodňového rizika sa $\mathrm{v}$ sledovanom období stala ešte jedna významná udalost', aj ked' z hl'adiska trvania epizodická. Bolo to zriadenie splnomocnenca vlády pre územnú samosprávu, integrovaný manažment povodí a krajiny v roku 2010. Jeho pôsobenie však trvalo len do roku 2012. Bližšie sa o tom zmienime v d’alšej časti príspevku. Zoznam aktérov súčasnej organizácie a riadenia povodňového rizika $\mathrm{v}$ SR je uvedený $\mathrm{v}$ tab. 4.

Tab. 4. Zoznam aktérov správy povodňového rizika

\begin{tabular}{|c|c|c|c|}
\hline & Orgány ústrednej štátnej správy & $\begin{array}{l}\text { Orgány miestnej } \\
\text { štátnej správy }\end{array}$ & Orgány samosprávy \\
\hline \multirow{11}{*}{ Aktéri } & organizácie MŽP SR: & \multirow{11}{*}{$\begin{array}{l}\text { okresné úrady v sídle } \\
\text { kraja, okresné úrady }\end{array}$} & \multirow[t]{11}{*}{ obce, vyššie územné celky } \\
\hline & Slovenský vodohospodársky podnik, š. p. & & \\
\hline & Výskumný ústav vodného hospodárstva & & \\
\hline & Vodohospodárska výstavba, š. p. & & \\
\hline & Hydrometeorologicky ústav & & \\
\hline & & & \\
\hline & organizácie MPRV SR: & & \\
\hline & Lesy Slovenskej republiky & & \\
\hline & Lesopol'nohospodársky majetok Ulič, & & \\
\hline & Hydromeliorácie, Štátne lesy Tatranského & & \\
\hline & národného & & \\
\hline
\end{tabular}

\section{Dimenzia: moc a zdroje}

Základným zdrojom financovania starostlivosti o vodné toky a protipovodňovej ochrany sú finančné zdroje zo štátneho rozpočtu. Tie sú však poskytované takmer výlučne organizáciám ústrednej štátnej správy. Orgánom samospráv na preventívnu protipovodňovú ochranu nie sú zo štátneho rozpočtu poskytované žiadne finančné prostriedky. Ďalším zdrojom sú financie z európskych štrukturálnych, resp. kohéznych fondov. Ich žiadatel'mi sú spravidla opät' organizácie ústrednej štátnej správy. Obce a vyššie územné celky sú ojedinelými žiadatel’mi. 
Zabezpečovanie ochrany pred povodňami je finančne náročné. Finančné zdroje na starostlivost' o vodné toky a na výstavbu, úpravu a údržbu technickej protipovodňovej infraštruktúry zo štátneho rozpočtu sú dlhodobo nedostatočné a nezodpovedajú požiadavkám SVP, š. p. (Solín 2015). Napr. v období rokov $2001-2010$ požadoval SVP, š. p., na protipovodňovú ochranu 611 mil. eur. Z verejných zdrojov mu však bolo poskytnutých len 181 mil. eur. A v období rokov 2010 - 2015 vláda SR poskytla SVP, š. p., na ochranu pred povodňami 94 mil. eur.

\section{Dimenzia: pravidlá riadenia}

Pôsobnost' aktérov manažmentu povodňového rizika a vzájomné vzt'ahy medzi nimi vymedzuje legislatíva. Legislatíva o ochrane pred povodňami sa postupne spresňovala, ale bola tvorená tak, aby zachovala výlučnú zodpovednost' štátu za ochranu pred povodňami. Súčasný legislatívny rámec vytvára silno centralizovanú štátnu štruktúru organizácie a riadenia povodňového rizika, v ktorej rozhodujúcim subjektom správy je SVP, š. p. Vykonávanie správy povodňového rizika je vertikálne dekoncentrované, t. j. pôsobnost' správy je vykonávaná odštepnými závodmi na vymedzených územiach, ktoré sú podriadené podnikovému riaditel'stvu SVP, š. p., a správam povodí podriadeným odštepným závodom. Ostatné subjekty ochrany pred povodňami (okresné úrady v sídle kraja, okresné úrady, obce, VUC a správcovia drobných tokov) sú právne a pracovne nižšie postavené a ich činnost' na úseku preventívnej ochrany pred povodňami je viazaná na spoluprácu so SVP, š. p.

Implementáciou smernice EÚ o hodnotení a manažmente povodňových rizík (Smernica EU 2007) do nášho legislatívneho systému (Zákon č.7/2010 Z. z.) sa výrazne zmenil legislatívny rámec riešenia problematiky povodní oproti dovtedy platnému zákonu (Zákon č. 666/2004 Z. z.). Pôsobnost' orgánov štátnej správy zodpovedných za ochranu pred povodňami, správcov vodných tokov a právnických a fyzických osôb sa podl'a Zákona č. 666/2004 Z. z. týkala predovšetkým organizovania a vykonávania povodňových zabezpečovacích a záchranných prác $\mathrm{v}$ čase nebezpečenstva povodne, počas povodne a po povodni. Zákon (Zákon č.7/2010 Z. z.) však ich pôsobnost' rozšíril o novú a významnú činnost', ktorá zahrnuje vypracovanie predbežného hodnotenie povodňového rizika, máp povodňového ohrozenia, máp povodňového rizika a plánov manažmentu povodňového rizika a ich následné prehodnocovanie a aktualizáciou v určených časových intervaloch.

\section{Dimenzia: vecné zameranie}

Koncept ochrany pred povodňami technickou infraštruktúrou budovanou na vodných tokoch a $\mathrm{v}$ ich blízkosti je pri riešení problematiky povodní stále dominantný. Opatrenia na zvýšenie infiltračnej a retenčnej schopnosti povodí majú v navrhovaných plánoch manažmentu povodňového rizika len deklaratívny charakter a navyše vôbec sa v nich nevenuje pozornost' stratégiám zameraným na redukciu zranitel'nosti a zmierňovanie negatívnych dôsledkov povodní. Spôsob implementácie smernice EÚ (Smernica EU 2007) do legislatívneho systému, ked' úlohy smernice boli považované len za jedno z viacerých preventívnych protipovodňových opatrení, do určitej miery potlačil konceptuálny rámec integrovaného hodnotenia a manažmentu povodňového rizika.

Z uvedenej analýzy vyplýva, že správa povodňového rizika v SR je centralizovane riadená štátom formou dekoncentrovanej správy a stratégia manažmentu povodňového rizika je výlučne zameraná na ochranu pred povodňami. Ak by sme, 
vzhl'adom na zmeny v štyroch dimenziách verejnej služby, mali vyjadrit' dynamiku správy povodňového rizika jedným zo spôsobov zmien prezentovaných $\mathrm{v}$ tab. 2 , tak do úvahy prichádza spôsob, ktorý je pomenovaný ako vrstvenie. Pretrvávajúca centralizovaná správa povodňového rizika a dôraz $\mathrm{v}$ manažmente povodňového rizika položený na ochranu pred povodňami je výsledkom toho, že sily stability mali prevahu nad silami zmeny. Ich podrobnejšou charakteristikou sa zaoberáme v nasledujúcej časti.

\section{HODNOTENIE VPLYVU SÍL STABILITY A SÍL ZMENY NA SPRÁVU POVODŇOVÉHO RIZIKA}

\section{Sily stability}

Komunistický režim niekol'ko desat'ročí neumožňoval zíst' z cesty štátom centralizovane riadenej ochrany pred povodňami. V procese industrializácie Slovenska bolo vybudovaných viacero vel'kých vodných elektrární, ktoré plnili aj funkciu ochrany pred povodňami. A tie, ako aj d'alšie vybudované vodné diela spolu s ochrannými hrádzami na stredných a dolných úsekoch hlavných vodných tokov položili základ technickej protipovodňovej infraštruktúry v SR. Sprievodným znakom tohto procesu bola výchova širokej vrstvy odborne zdatných pracovníkov na vysokých školách, schopných vybudovat' vodné diela, zabezpečit' ich prevádzku a údržbu.

Decentralizácia verejnej správy na štátnu správu a samosprávu po zmene spoločenského systému v roku 1989 však nevyvolala tlak na decentralizáciu správy povodňového rizika. Tendencia udržat' existujúci stav je prejavom teórie zotrvačnosti. $\mathrm{V}$ jej pozadí je predovšetkým úzke prepojenie a spolupráca medzi organizáciami ústrednej štátnej správy zabezpečujúcimi úlohy vodného hospodárstva. Dôležitú úlohu zohráva aj spolupráca organizácií vodného hospodárstva s technickými vysokými školami, ako aj ich schopnost' ovplyvňovat' verejnú mienku a presviedčat' verejnost' o nepostrádatel'nosti budovania technickej protipovodňovej infraštruktúry na ochranu pred povodňami a o výlučnej zodpovednosti štátu za jej budovanie. $\mathrm{K}$ zachovaniu existujúceho stavu prispieva aj nezáujem miestnych samospráv o správu vodných tokov, ktoré pretekajú cez ich katastrálne územie, a nízke povedomie verejnosti o povodňovom riziku. Obce nemajú záujem o správu drobných vodných tokov, pretože zo strany štátu im nie sú poskytované žiadne finančné zdroje na starostlivost' o vodné toky.

\section{Sily zmeny}

Extrémne hydrologické javy odkrývajú kritické miesta existujúcej správy povodňového rizika a otvárajú okno príležitostí pre uplatnenie alternatívnych stratégií manažmentu a správy povodňového rizika. Politika zmeny sa pritom môže uskutočnit' $\mathrm{v}$ rôznych analytických rámcoch. V období od 50 . rokov 20 , storočia sa okno príležitostí na zmenu otvorilo v podstate trikrát. Prvýkrát to bolo v roku 1965. Pod vplyvom extrémnej povodne na Dunaji vtedajšie ústredné štátne orgány zodpovedné za vodné hospodárstvo dospeli k názoru, že existujúca organizačná štruktúra vodného hospodárstva na báze OVHS nie je efektívna z hl'adiska riešenia problematiky povodní, a preto vláda ČSSR prijala rozhodnutie o novom organizačnom usporiadaní vodného hospodárstva (analytický rámec zmeny: koalícia aktérov). 
Potom nasledovalo obdobie, počas ktorého ojedinelými kritikmi vodohospodárskej politiky v SR boli organizácie ochrany prírody. Po roku 1989 sa aktivita environmentálnych mimovládnych organizácií, kritická voči štátnej politike vodného hospodárstva, zvýšila. Kritikou sa snažili presadit', aby sa pri riešení problémov s vodami okrem názoru úzkej skupiny expertov vodného hospodárstva rešpektoval aj názor zainteresovanej verejnosti. Ich výhrady spočiatku smerovali predovšetkým k plánovanej výstavbe konkrétnych vodohospodárskych diel. Poukazovali najmä na devastujúci účinok vodných nádrží na životné prostredie a neboli presvedčení ani o nevyhnutnosti ich budovania a o ich ekonomickej efektívnosti.

V júli 1998 sa okno príležitostí otvorilo po druhýkrát. Počas prietrže mračien napršalo v oblasti hornej časti Svinky viac ako $100 \mathrm{~mm}$ zrážok. Následná povodeň zasiahla 62 obcí. Najtragickejším následkom tejto povodne bola strata 50 l’udských životov v obci Jarovnice. Táto extrémna hydrologická udalost' vel'mi zretel'ne poukázala na potrebu diverzifikovaného manažmentu povodňového rizika, ktorého neoddelitel'nou súčast'ou bude aj znižovanie zranitel'nosti obyvatel'ov voči povodňovému ohrozeniu a zvýšenie ich pripravenosti odolávat' povodniam a schopnosti vyrovnat' sa s ich negatívnymi dôsledkami. Orgány zodpovedné za ochranu pred povodňami a ani mimovládne organizácie však necítili potrebu menit' pretrvávajúcu stratégiu ochrany pred povodňami.

Určitý posun v aktivitách mimovládnych organizácií nastal v roku 2010, ked' sa okno príležitostí otvorilo po tretíkrát. V tomto roku sa udiali dve významné udalosti, ktoré boli impulzom k určitej zmene protipovodňovej politiky. Prvou udalost'ou bol rozsiahly výskyt povodní na celom území Slovenska. Okrem zaplavenia spôsobeného vybrežením vodných tokov dochádzalo aj $\mathrm{k}$ častému výskytu záplav v dôsledku vody tečúcej zo svahov, ako aj vysokej hladiny podzemnej vody. Tieto extrémne povodne vytvorili pre environmentálne organizácie príležitost' na prezentáciu alternatívneho spôsobu manažmentu povodňového ohrozenia, ktorý kládol dôraz na aplikáciu preventívnych protipovodňových opatrení, zameraných na zadržiavanie dažd'ovej vody v krajine a spomal'ovanie jej odtoku (Kravčík et al. 2012).

Druhou udalost'ou boli parlamentné vol'by, po ktorých sa zmenila mocenská garnitúra. Nová politická zostava mala pochopenie pre navrhovaný alternatívny spôsob manažmentu povodňového rizika a zriadila funkciu splnomocnenca vlády pre územnú samosprávu, integrovaný manažment povodí a krajiny (analytický rámec zmeny: viacnásobné línie). Splnomocnenec vlády pre územnú samosprávu, integrovaný manažment povodí a krajiny sa tak stal novým aktérom v organizácii a riadení povodňového rizika. Jeho úlohou bolo zabezpečit' realizáciu projektu „Program revitalizácie krajiny a integrovaného manažmentu povodí Slovenskej republiky“ (Úrad vlády SR 2010), v rámci ktorého bol dôraz položený predovšetkým na budovanie malých technických stavieb na drobných vodných tokoch a v pol'nohospodárskej a lesnej krajine.

Prezentovanie uvedeného programu ako koncepcie, ktorá by mala byt' novou stratégiou manažmentu povodňového rizika v SR, sa nestretlo s pochopením, predovšetkým u dominantného aktéra manažmentu povodňového rizika, SVP, š. p. Problematický spôsob samotnej realizácie programu, ktorá nadobudla charakter masívneho a nepremysleného budovania prehrádzok z prírodných materiálov na malých vodných tokoch po celom území SR, ktoré však nemali dlhodobú účinnost', sa ale nestretol s pochopením a podporou ani v širšej odbornej verejnosti. Po predčasných parlamentných vol'bách v marci roku 2012 sa zmenila politická garnitúra a 
nová vláda prestala program podporovat' a funkciu splnomocnenca pre územnú samosprávu, integrovaný manažment povodí a krajiny zrušila.

\section{ÚVAHA NAD ZMENAMI V SPRÁVE POVODŇOVÉHO RIZIKA V SR}

Po neúspešnom pokuse o určitú decentralizáciu a diverzifikáciu manažmentu povodňového rizika v rokoch 2010 - 2012 je stále namieste otázka, či v kontexte zvládnutia narastajúceho povodňového rizika v dôsledku meniacej sa klímy a krajiny je centralizovaná správa povodňového rizika a pretrvávajúca koncepcia ochrany pred povodňami skutočne tým optimálnym variantom správy povodňového rizika v SR. Sme toho názoru, že nie. $Z$ viacerých argumentov v neprospech zachovania súčasnej stratégie a správy povodňového rizika za klúčové považujeme nasledovné tri.

Prvým argumentom je finančná náročnost' budovania, prevádzky a údržby technickej protipovodňovej infraštruktúry. $Z$ verejných zdrojov, ako už bolo uvedené, sa dlhodobo nedarí vyčlenit' požadované finančné prostriedky na protipovodňovú ochranu, čo zvyšuje riziko záplav v dôsledku poškodenia nedostatočne udržovanej technickej infraštruktúry. Predstava, že negatívnym dôsledkom povodní spôsobovaných zvyšovaním frekvencie výskytu povodňových situácií, ako aj ich extrémnosti, dokážeme zabránit' len d'alším budovaním vodných nádrží, poldrov, ochranných hrádzí a technickou úpravou korýt vodných tokov je iluzórna. Nie je možné (nedostatok financií) ani žiaduce (environmentálny aspekt) budovat' technické protipovodňové opatrenia $\mathrm{v}$ každej obci, v ktorej sa vyskytne povodeň. Absolútna ochrana pred povodňami neexistuje. A určitá úroveň povodňového ohrozenia musí byt' spoločnost'ou akceptovaná.

Druhým argumentom je, že stratégia ochrany pred povodňami nevenuje dostatočnú pozornost' pluviálnej povodňovej hrozbe, resp. sa ňou zaoberá len deklaratívne, napriek tomu, že táto forma povodňového ohrozenia na Slovensku je rovnako významná ako fluviálne povodňové ohrozenie. Slovensko je hornatá a navyše Z väčšej časti aj rurálna krajina. Z celkového počtu 2890 obcí Slovenska v roku 2011 malo až 2752 obcí vidiecky charakter a žije v nich takmer $46 \%$ obyvatel'ov (c.f. Székely 2016). Analýza výskytu povodňových situácií za obdobie rokov 1996 - 2006 ukázala, že v uvedenom období bolo povodňou postihnutých 1367 obcí, t. j. $47 \%$ z celkového počtu, z toho bolo 920 obcí t. j. $67 \%$ lokalizovaných pozdĺž drobných vodných tokov (Solín 2008). Mimoriadne dôležitá je však skutočnost', že pri povodňových situáciách okrem regionálnych povodní (1 052) bol významný aj výskyt bleskových povodní (1 061 povodňových situácií). Sprievodným znakom bleskových povodní okrem vybreženia vodného toku je rozsiahly výskyt povodňového ohrozenia v dôsledku vody tečúcej zo svahov polí a lesov (pluviálne povodňové ohrozenie). Dôležitým aspektom povodňového ohrozenia vo vidieckych obciach je okrem morfologicko-pôdno-substrátových vlastností povodí a využívania krajiny aj vplyv d'alších lokálnych faktorov na povodňové ohrozenie, ako je napr. zanedbaná starostlivost' o korytá vodných tokov a príbrežných pozemkov, spôsobujúcich upchatie rôznych premostení a následné vybreženie vodných tokov. Z výskumu povodňového rizika na báze dotazníkového prieskumu v obciach myjavského regiónu (Solín et al. 2017) vyplynulo, že v súvislosti so znížením povodňového ohrozenia obyvatelia považujú za dôležitú predovšetkým systematickú údržbu drobných vodných tokov a zlepšenie hospodárenia $\mathrm{v}$ lesoch a na pol'nohospodárskej pôde. V prípade vidieckych obcí je pluviálne povodňové ohrozenie význam- 
ným javom a jeho riešenie prostredníctvom budovania finančne náročných poldrov na vodných tokoch nie je vhodné.

Tretím významným argumentom v prospech zmeny správy povodňového rizika v SR je zmena paradigmy povodňového rizika. Centrálnou myšlienkou súčasných adaptačných stratégií manažmentu povodňového rizika na klimatické zmeny nie je samotná ochrana pred povodňami, ale zvýšenie schopnosti spoločnosti odolávat' povodniam a vyrovnat' sa s ich negatívnymi dôsledkami - angl. „resilience“ (APFM 2006, ISDR/UN 2007, Sapoutzaki 2012, Hegger et al. 2016, Priest et al. 2016 a McEwena et al. 2018). Zvyšovanie spomínanej „resilience“ (odolnosti) spoločnosti si vyžaduje diverzifikovaný a decentralizovaný manažment povodňového rizika (Hegger et al. 2016). Diverzifikovný prístup k manažmentu povodňového rizika okrem ochrany pred povodňami zahrnuje aj redukciu povodňového ohrozenia prostredníctvom územného plánovania, realizáciu opatrení na zvýšenie retenčnej kapacity povodí. Neoddelitel'nou súčast'ou diverzifikovaného prístupu je zvýšenie povedomia verejnosti o povodňovom riziku a jej spoluúčasti na redukcii povodňového rizika - či už formou znižovania zranitel'nosti, zvyšovania schopnosti odolávat' povodňovému ohrozeniu a schopnosti vyrovnat' sa s negatívnymi následkami povodní (APFM 2006 a Mees et al. 2016).

Súčasná centralizovaná správa povodňového rizika v SR prostredníctvom SVP, š. p., nedokáže efektívne zabezpečit' diverzifikáciu manažmentu povodňového rizika, a preto sa jej decentralizácia javí ako nevyhnutný krok. Jadrom decentralizovanej správy povodňového rizika je jej hierarchická štruktúra, t. j. správa povodňového rizika na národnej, regionálnej a lokálnej úrovni, ktorá si vyžaduje stanovenie aktérov manažmentu povodňového rizika na národnej, regionálnej a lokálnej úrovni s presne vymedzenou zodpovednost'ou, finančnými zdrojmi a stanovenými komunikačnými kanálmi na zabezpečenie zosúladenia ciel'ov manažmentu jednotlivých hierarchických úrovní. Legislatívne stanovenie orgánov ústrednej štátnej správy a miestnej štátnej správy na jednej strane a orgánov samosprávy na strane druhej, vzbudzuje dojem určitej decentralizovanej správy povodňového rizika. Participácia okresných úradov, obcí a VÚC na manažmente povodňového rizika je však len formálna, pretože nedisponujú žiadnymi finančnými zdrojmi ani primeranými reálnymi právomocami na aktívny manažment povodňového rizika na lokálnej, resp. regionálnej úrovni. Dôležitou legislatívnou prekážkou aktívnej účasti obcí na starostlivosti o vodné toky, ktoré pretekajú cez ich katastrálne územie, je skutočnost', že obce nie sú správcami týchto vodných tokov.

Diverzifikovaný prístup okrem decentralizácie správy povodňového rizika si vyžaduje aj adekvátne poznatky o povodňovom riziku. Tu je potrebné zdôraznit', že hodnotenie povodňového rizika, ktorého výstupom je stanovenie riečnych úsekov vodných tokov kritických z hl'adiska vybreženia (obr. 1) je síce dôležité z hl'adiska aplikácie technických protipovodňových opatrení, ale nie je postačujúce na uplatnenie diverzifikovaného súboru stratégií na zníženie povodňového rizika. Vyžaduje sa nový prístup k hodnoteniu povodňového rizika, ktorý je založený na systematickom spracovaní údajov o faktoroch ovplyvňujúcich povodňové ohrozenie katastrálneho územia a zranitel'nost' jeho sociálneho, ekonomického a environmentálneho systému. Príklad takéhoto hodnotenia je v prípadovej štúdií Solín a Rusnák (2020). Záverečným výstupom hodnotenia je stanovenie indexu potenciálu povodn̆ového rizika (IPFR) katastrálnych území (obr. 2). 


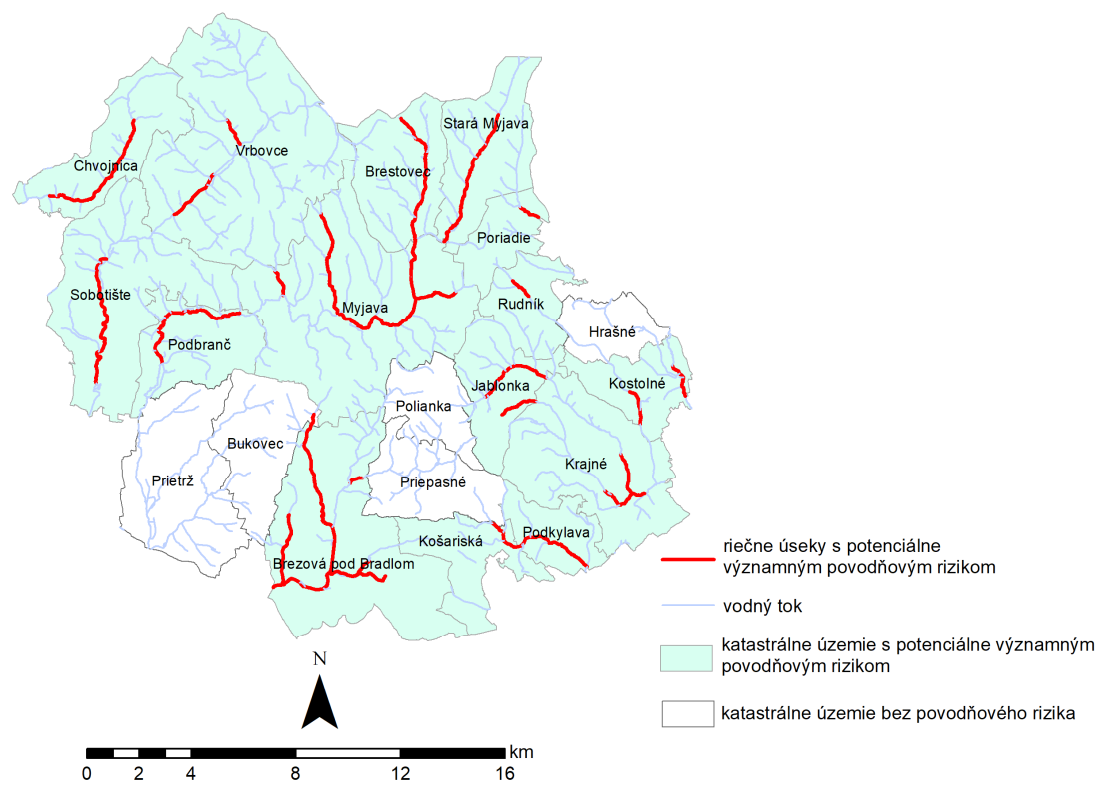

Obr. 1. Riečne úseky v katastrálnych územiach s potenciálne významným povodňovým rizikom (MŽP SR 2011)

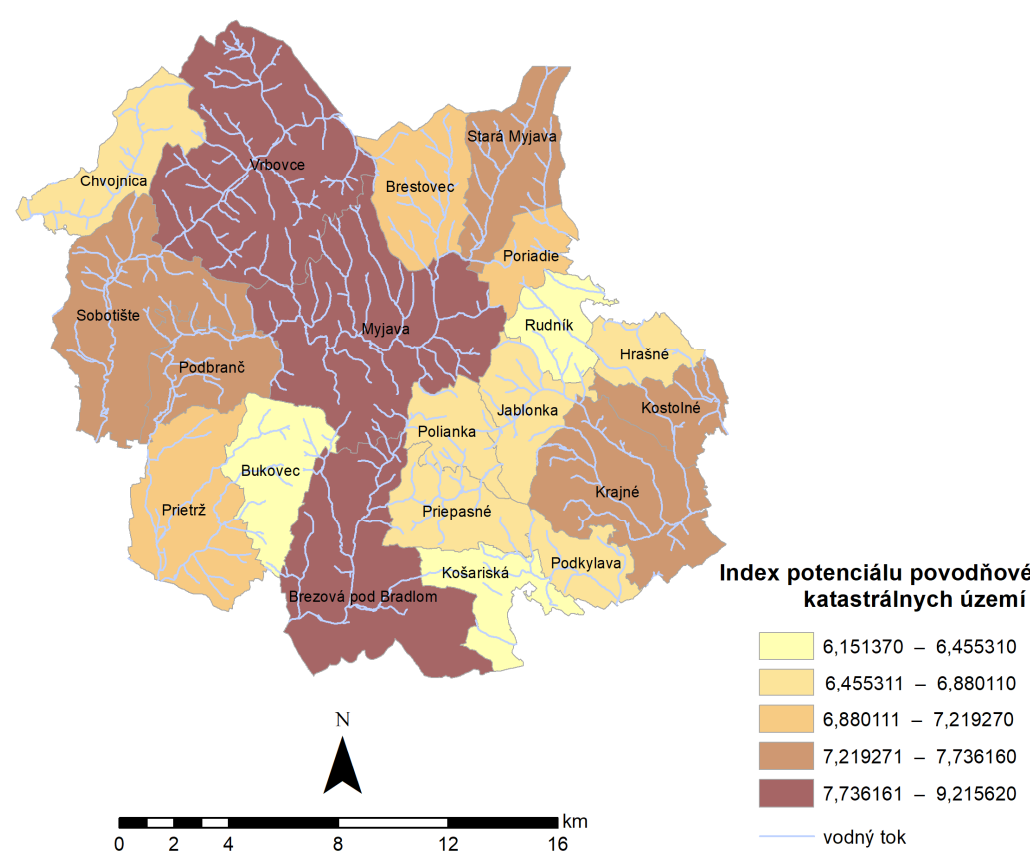

Obr. 2. Priestorová diferenciácia katastrálnych územní z hl’adiska potenciálu povodňového rizika (upravené podl'a Solína a Rusnáka 2020) 


\section{ZÁVEREČNÉ POZNÁMKY}

V príspevku je prezentovaný vývoj správy povodňového rizika v SR a analýza jej dynamiky z hl’adiska základných dimenzií správy verejnej služby (aktéri, moc a zdroje, pravidlá riadenia a vecné zameranie) a pôsobenia síl stability a zmeny. $Z$ analýzy vyplýva, že napriek viacerým impulzom (ako boli napr. extrémne hydrologické javy, zmena spoločenského systému, implementácia legislatívy EÚ, či zmena politickej moci) pretrváva centralizované riadenie správy povodňového rizika formou dekoncentrovanej správy, ako aj zameranie protipovodňovej politiky výlučne na ochranu pred povodňami technickou infraštruktúrou. Tendencia udržat' existujúci stav je prejavom teórie zotrvačnosti. Napriek centralizovanému štátnemu riadeniu je možné pozorovat' určitú dynamiku správy povodňového rizika. Základným impulzom $\mathrm{k}$ výraznejším zmenám $\mathrm{v}$ dimenzii aktérov správy povodňového rizika boli extrémne hydrologické javy v roku 1965 a 2010 a v dimenzii týkajúcej sa pravidiel riadenia to bola implementácia smernice EÚ a hodnotení manažmentu povodňových rizík (Smernica EÚ 2007). Snaha o určitú decentralizáciu a diverzifikáciu manažmentu povodňového rizika vznikla v roku 2010, a to zriadením funkcie splnomocnenca pre územnú samosprávu, integrovaný manažment povodí a krajiny. Po zmene politickej garnitúry v roku 2012 bola funkcia splnomocnenca zrušená.

Presadzovanie konceptu ochrany územia pred zaplavením v dôsledku vybreženia vodného toku a centralizované riadenie správy manažmentu povodňového rizika je z dlhodobého hladiska neudržatel'né. Klimatické zmeny, zmeny krajinnej pokrývky, ako aj hodnotového systému spoločnosti v prospech trvalo udržatel'ného environmentálneho systému si vyžadujú zmenu základnej stratégie protipovodňovej politiky. A od ochrany pred povodňami bude nevyhnutné prejst' $\mathrm{k}$ stratégii, ktorej hlavným ciel'om je zvyšovanie schopnosti spoločnosti odolávat' povodniam a vyrovnat' sa s ich negatívnymi dôsledkami. Nevyhnutným predpokladom naplnenia tohto ciela je aplikácia diverzifikovaného súboru stratégií a decentralizovaný manažment povodňového rizika s jasne špecifikovanými aktérmi správy povodňového rizika na lokálnej, regionálnej a národnej úrovni a stanovením ich pôsobnosti, ktorej vykonávanie bude zabezpečené legislatívou a adekvátnymi zdrojmi. Nevyhnutnou súčast’ou diverzifikovaného manažmentu je aj zmena prístupu $\mathrm{k}$ hodnoteniu povodňového rizika. Riešenie decentralizácie a diverzifikácie manažmentu povodňového rizika ako je aj jeho integrované hodnotenie si vyžaduje multidisciplinárny prístup, v rámci ktorého geografický výskum má nezastupitel'né miesto.

Príspevok je určitým impulzom $\mathrm{k}$ diskusii o tom, ako d'alej pokračovat' $\mathrm{v}$ riešení problematiky povodní na Slovensku. Jej jadrom by nemali byt' požiadavky na výrazné zvýšenie finančných prostriedkov na technickú protipovodňovú ochranu, ani návrat $\mathrm{k}$ nepremyslenému presadzovaniu budovania prehrádzok na vodných tokoch. Diskusia by mala byt' o systematickej zmene politiky manažmentu povodňového rizika, $\mathrm{v}$ ktorej by sa prehodnotila opodstatnenost' súčasného strategického ciel'a manažmentu povodňového rizika a spôsobu identifikovania oblastí s potenciálne významným povodňovým rizikom i možnost' uplatňovania diverzifikovaných prístupov redukcie povodňového rizika prostredníctvom decentralizovanej správy povodňového rizika.

Príspevok bol vypracovaný v rámci riešenia projektu 2/0006/18 Integrované hodnotenie povodňového rizika: východisko pre aktualizáciu plánov manažmentu povodňového rizika, ktorý je finančne podporovaný grantovou agentúrou VEGA. 


\section{LITERATÚRA}

APFM (2006). Social aspects and stakeholder involvement in integrated flood management. Geneva (World Meteorological Organization Global Water Partnership and Asian Disaster Preparedness Center).

ARTHUR, W. B (1988). Self-reinforcing mechanisms in economics. In Anderson, P. W., Arrow, K., Pines, D., eds. The economy as an evolving complex system. Santa Fe (Westview press), p. 336.

BUBECK, P., KREIBICH, H., PENNING-ROWSELl, E. C., BOTZEN, W. J. W., De MOEL, H., KLIJN, F. (2017). Explaining differences in flood management approaches in Europe and in the USA - comparative analysis. Journal of Flood Risk Management, 10, 436-445.

Di BALDASSARRE, G., KREIBICH, H., VOROGUSHYN, S., AERTS, J., ARNBJERGNIELSEN, K., BARENDRECHT, M., BATES, P., BORGA, M., BOTZEN, W., BUBECK, P., DE MARCHI, B., LLASAT, C., MAZZOLENI, M., MOLINARI, D. MONDINO, E., MÅRD, J., PETRUCCI, O., SCOLOBIG, A., VIGLIONE, A., WARD, P. J. (2018). Hess opinions: An interdisciplinary research agenda to explore the unintended consequences of structural flood protection. Hydrology Earth System Sciences, 22, 5629-5637.

FOURNIER, M., LARRUE, C., SCHELlENBERGER, T. (2018). Changes in flood risk governance in France: a David and Goliath story? Journal of Flood Risk Management, $11,261-270$.

JOHNSON, C. L., TUNSTALL, S. M., PENNING-ROWSELL, E. C. (2005). Floods as catalysts for policy change: historical lessons from England and Wales. International Journal of Water Resources Development, 21, 4, 561-575.

HANUŠIN, J. (1986). Vplyv podzemných vôd na krajinnú štruktúru Ondavskej roviny. Kandidátska dizertačná práca, Geografický ústav SAV, Bratislava.

HEGGER, D., DRIESSEN, P., BAKKER, M., eds. (2016). A view on more resilient flood risk governance: Key conclusions of the STAR-FLOOD project. Utrecht (STAR-FLOOD consortium).

ISDR/UN (2007) Hyogo framework for action 2005 - 2015. Building the resilience of nations and communities to disasters. International strategy for disaster reduction. Geneva (United Nations).

JAMBOR, J. (2016). 50 rokov vzniku podnikov Povodí na Slovensku. Vodohospodársky spravodajca, 59(7-8), 19-22.

KAUFMANN, M. (2018). Limits to change - institutional dynamics of Dutch flood risk governance. Journal of Flood Risk Management, 11, 250-260.

KLIJN, F., SAMUELS, P., van OS, A. (2008). Towards flood risk management in the EU: State of affiers with examples from various European countries. International Journal of River Basin Management, 6, 307-321.

KRAVČÍK, M., KOHUTIAR, J., GAŽOVIČ, M., KOVÁČ, M., HRÍB, M., ŠUTY, P. KRAVČ́KOVA, D. (2012). Po nás púšt' a potopa? Banská Bystrica (MVO Ludia a voda).

LIFFERINK, D., WIERING, M., CRABBÉ, A., HEGGER, D. (2018). Explaining stability and change. Comparing flood risk governance in Belgium, France, the Netherlands and Poland. Journal of Flood Risk Management, 11, 281-290.

McEWENA, L., HOLMESA, A., QUINNA, N., COBBING, P. (2018). Learning for resilience': Developing community capital through flood action groups in urban flood risk settings with lower social capital. International Journal of Disaster Risk Reduction, 27, 329-342.

MATCZAK, P., LEWANDOWSKI, A., SZWED, M., KUNDZIEWICZ, Z. W. (2018). Doing more while remaining the same? Flood risk governance in Poland. Journal of Flood Risk Management, 11, 239-249

MEES, H., CRABBE, A., ALEXANDER, M., KAUFMAN, M., BRUZZONE, S., LÉVY, L., LEWANDOWSKI, J. (2016). Coproducing flood risk management through citizen 
involvement: Insights from cross-countryn comparison in Europe. Ecology and Society, 21(3):7. DOI: http://dx.doi.org/10.5751/ES-08500-210307.

MEES, H., CRABBE, A., SUYKENS, C. (2018). Belgian flood risk governance: Explaining the dynamics within a fragmented governance arrangement. Journal of Flood Risk Management, 11, 3, 271-280.

MORRIS, J., BEEDELL, J., HESS, T.M. (2016). Mobilising flood risk management services from rural land: principles and practice. Journal of Flood Risk Management, 9, 5068.

MŽP SR (2011). Predbežné hodnotenie povodňového rizika v čiastkovom povodí Moravy. Implementácia smernice Európskeho parlamentu a Rady 2007/60/ES z 23. októbra 2007 o hodnotení a manažmente povodňových rizík. Bratislava (Ministerstvo životného prostredia SR).

NORTH, D.C (1990). Institutions, institutional change and economic preformance. Cambridge (University Press).

NOVÁK, L. (2016). Padesát let podniku Povodí. Vodní hospodářství, 66, 3, 14-17.

PLATE, E. J. (2002). Flood risk and flood management. Journal of Hydrology, 267, 2-11.

PIERSON, P. (2000). Increasing returns, path dependence, and study of politics. American Political Science Review, 2, 251-267.

PRIEST, S. J., SUYKENS, C., Van RIJSWICK, H. F. M. W., SCHELLENBERGER, T., GOYTIA, S., KUNDZEWICZ, Z. W., van DOORN-HOEKVELD, W. J., BEYERS, J.C., HOMEWOOD, S. (2016). The European Union approach to flood risk management and improving societal resilience: Lessons from the implementation of the Floods directive in six European countries. Ecology and Society, 21(4):50. DOI: https:// doi.org/10.5751/ES-08913-210450.

SAPOUTZAKI, K. (2012). Vulnerability management by means of resilience. Natural Hazards, 60, 1267-1285.

Smernica EÚ (2007). Smernica Európskeho parlamentu a Rady 2007/60/ES o hodnoteni a manažmente povodňových rizík. Úradný vestník Európskej únie L288/27.

SOLÍN, L'. (2008). Analýza výskytu povodňových situácií na Slovensku v období rokov rokov1996 - 2006. Journal of Hydrology and Hydromechanics, 56, 95-115.

SOLÍN, L. (2015). Recent Slovak flood protection relative to integrated flood risk management. International Journal River Basin Management, 13, 463-473.

SOLÍN, L', SLÁDEKOVÁ MADAJOVÁ, M., MICHALEJE, L. (2017). Flood hazard in the headwaters area: Lessons learned from a survey of households in the upper Myjava basin, Slovakia. Water Policy, 19, 1081-1096

SOLÍN, L., RUSNÁK, M. (2020). Preliminary flood risk assessment: Case study of systematic processing of available or readily derivable information. Water and Environmental Journal, DOI:10.1111/wej.12570.

STREECK, W., THELEN, K. (2005). Beyond continuity: Explorations in the dynamics of advanced political economies. Oxford (Oxford Univesity Press).

SZÉKELY, V. (2016). Different approaches to the urban-rural typology: Different views on distribution of urban and rural population in Slovakia. Acta Geobalcanica, 2, 27-34.

SVP (2018). Výročná správa za rok 2018. Slovenský vodohospodársky podnik, š.p., [Online]. Dostupné na: https://www.svp.sk/wp-content/uploads/2012/11/VS2018opravena-web.pdf [cit.: 20-01-2020].

VONDRUS̊KOVA, M. (2012). Vývoj českého vodního práva za první republiky. Diplomová práca. Západočeská univerzita v Plzni, Plzeň.

Vyhláška (1978). Vyhláška č. 6. Ministerstva lesného a vodného hospodárstva zo 16. januára 1978, ktorou sa určujú povinnosti správcov vodných tokov a uspravujú sa niektoré otázky týkajúce sa vodných tokov.

Úrad vlády SR (2010). Program revitalizácie krajiny a integrovaného manažmentu povodí SR a návrh jeho realizačného projektu 2010. Uznesenie vlády SR č. 744/2010.

WERRITY, A. (2006). Sustainable flood management: Oxymoron or new paradigm, Area, $38,16-23$. 
WIERING, M., KAUFMANN, M., MEES, H., SCHELLENBERGER, T., GANZEVOORT, W., HEGGER, D. L. T., LARRUE, C., MATCZAK, P. (2017). Varieties of flood risk governance in Europe: How do countries respond to driving forces and what explains institutional change? Global Environmental Change, 44, 15-26.

WIERING, M., LIEFFERINK, D., CRABBÉ, A. (2018). Stability and change in flood risk governance: On path dependencies and change agents. Journal of Flood Risk Management, 11, 230-238.

WISNER, B., BLAIKIE, P., CANNON, T., DAVIS, I. (2004). At risk: Natural hazards, people's vulnerability, and disasters, second ed. London (Routledge).

Vládne nariadenie 92 zo dňa 27. novembra 1953 Z. z., ktorým sa zriad'uje Ústredná správa vodného hospodárstva.

Zákon č. 11/1955 Z. z., z 23 marca 1955 o vodnom hospodárstve.

Zákon č. 36/1960 Z. z., z 9. apríla 1960 o územnom členení štátu.

Zákon č. 138/1973 Z. z., z 31. októbra 1973 o vodách (vodný zákon).

Zákon č. 135/1974 Z. z., z 19. decembra 1974 o štátnej správe vo vodnom hospodárstve.

Zákon č. 369/1990 Z. z., zo 6. septembra 1990 o obecnom zriadení.

Zákon č. 302/2001 Z. z., zo 4.júla 2001 o samospráve vyšších územných celkoch (zákon o samosprávnych krajoch).

Zákon č. 666/2004 Z. z., z 27. októbra 2004 o ochrane pred povodňami.

Zákon č. 180/2013 Z. z., z 19. júna 2013 o organizácii miestnej štátnej správy a o zmene a doplnení niektorých zákonov v zmení neskorších predpisov.

Zákon č.7/2010 Z. z., z 2 decembra 2009 o ochrane pred povodňami

Zákon č.71/2015 Z. z., z 12. marca 2015, ktorým sa mení a dopĺn̆a zákon č. 7/2010 Z.z. o ochrane pred povodňami a zmení zákona č.180/2013 Z.z.

www.starflood.eu

www.svp.sk/sk/uvodna-stranka/svp/organizacna-struktura/

$$
\text { Lubomir Solin }
$$

\section{FLOOD RISK GOVERNANCE IN SLOVAKIA: WILL WE GET CHANGE?}

Slovakia is a country where several significant social and political changes have taken place over the past 30 years. In 1989 the social and political system changed and a significant reorganization of state administration and self-government bodies at a regional and local level were set up. Slovakia became a member of the EU in 2004 and the implementation of directives and regulations of the European Parliament and the Council into its legislative system started. Slovakia became an open society in which non-governmental organizations had a significant influence in the public sector. In this context, the question is therefore whether these changes together with the ongoing climate change as well as the change in the flood risk paradigm have somehow been reflected in the flood risk governance. The aim of this paper is to answer this question by applying the analytical framework that was used by EU-FP7 STAR-FLOOD project to analyse the dynamics of flood risk governance.

Research into the dynamics of the governance flood risk was carried out on the basis of a Policy Arrangement Approach, an analytical framework assuming that the policy arrangement is characterized by four dimensions: 1) actors and coalitions of actors, 2) power and resources, 3) rules of games, and 4) discourse. Changes in individual dimensions are assessed in terms of the effect of the forces of stability and forces of change (Tab. 3). The forces of stability are manifested by the preservation of the existing state. A key aspect of the forces of stability is the path dependency theory, according to which the steps of the previous direction affect the future direction. In relation to the forces of change, three analytical frameworks conceptualize the policy of change: the multiple streams framework, the advocacy coalition framework, and the discourse analysis framework. 
A brief characteristic of the current flood risk governance in Slovakia in terms of four basic dimensions of public arragement is as follows:

The main actors of flood risk governance in Slovakia are: a) organizations of the Ministry of Environment of the Slovak Republic (Slovak Water Management Enterprise, Research Institute of Water Management, Water Management Construction Enterprise, and Slovak Hydrometeorology Institute), b) organizations of the Ministry of Agriculture and Rural Development of the Slovak Republic, (Forest-agricultural property Ulič, and Hydromelioration and State forests of the Tatra National Park), c) local state administration bodies (district offices), d) self-government bodies (municipalities and higher territorial units).

The main source of funding for watercourse management and flood protection are state budget funds, which are provided almost exclusively to central government organizations. The legislative framework creates a strongly centralized state structure of the flood risk governance. The decisive subject of the governance of flood risk is the Slovak Water Management Enterprise. Other entities, responsible for flood protection (district offices in the region seat, district offices, municipalities, higher territorial units, administrators of small watercourses), are legally and professionally inferior and their activity in the field of preventive flood protection is tied to cooperation with the Water Management Enterprise. The authorities responsible for flood protection have only very slowly changed the flood risk management strategy and have practically insisted on the exclusive implementation of the flood protection strategy by preferring to build technical flood control measures on the watercourses they manage.

An analysis of the chronology of the development of the organization and the assessment of the dynamics of the governance of flood risk in terms of public arrangement dimensions shows that certain changes have occurred in the actors' dimensions, and the flood protection legislation (rule dimension) has also been modified.

In terms of power and resources dimension, virtually nothing has changed with the fact that legitimate bidders for public funding as well as resources from the European Cohesion Funds are only organizations of central government. Nor have there been any changes in the substance of flood risk management (discourse dimension) and flood protection by technical measures still dominates.

The persistent state centralized governance of flood risk in Slovakia, as well as the focus of flood risk management only on flood protection, is the result of stability forces outweighing the forces of change. However, this type of flood risk governance is unsustainable in the long term and it will need some decentralization and diversification of flood risk management to enable society to adapt to climate change and increase the societal resilience to flood risk.

Article first received: January 2020

Article accepted: July 2020 